\title{
PROCEEDINGS OF THE
} CAMBRIDGE

\section{PHILOLOGICAL SOCIETY}

NO. 215 (NEW SERIES, NO. 35)

page 1 GRAEME BARKER, The archaeology of the Italian shepherd

20 DOROTHEA FREDE, The soul's silent dialogue: a non-aporetic reading of the Theaetetus

50 JOHN HENDERSON, Satire writes 'woman': Gendersong

81 M.D. REEVE, Conceptions

113 STEPHANIE WEST, Laertes revisited

144 FROMA I. ZEITLIN, Mysteries of identity and designs of the self in Euripides' Ion 
1989-90

President:

G. E. R. LLOYD

Council:

C. F. L. AUSTIN (Treasurer),

P. A. CARTLEDGE (Meetings Secretary),

N. HOPKINSON (Programme Secretary),

\section{J.T. KILLEN, J.R. PATTERSON, M. SCHOFIELD}

Editors of the Proceedings: R. L. HUNTER, M. M. MACKENZIE

The objects of the Society are the furtherance of classical studies in general, and in particular the discussion and publication of critical researches into the languges, literature and civilization of Greece and Rome.

Any person interested in the ancient world is eligible for membership. The subscription of a member resident in Cambridge is $£ 12.00$ annually, except that the subscription of a resident research

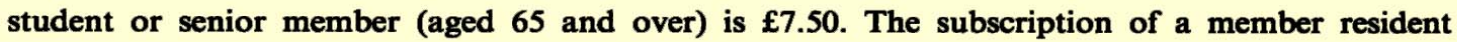
elsewhere is $£ 7.50$ annually. Members receive notices of all meetings of the Society and copies of the Proceedings.

Any library may subscribe to the Society and receive copies of the Proceedings. The subscription for libraries is $£ 15.00$ per annum.

The Society is responsible for two publications.

Proceedings of the Cambridge Philological Society, containing papers read to the Society and other articles by members, appears annually. The Editors welcome unsolicited contributions from members. Contributions intended for the Proceedings should be addressed to either Dr R. L. Hunter, Pembroke College, Cambridge CB2 1RF, or Dr M. M. Mackenzie, New Hall, Cambridge CB3 ODF.

Supplements to the Proceedings is an occasional series designed to accommodate works of intermediate size, i.e. of about $\mathbf{1 5 0}$ pages. Members of the Society are invited to submit proposals for monographs to be published in this series; proposals should be addressed to either of the Editors.

Applications for membership, and all other correspondence relating to the Society, should be addressed to Dr C. F. L. Austin, Trinity Hall, Cambridge CB2 1TJ. 